\title{
PERAN MANAJEMEN PEMBELAJARAN DALAM MENINGKATKAN KETERAMPILAN MEMBACA STUDI KASUS PADA BIMBA AIUEO PAMULANG
}

\author{
Rio Setiawan ${ }^{1}$, Fahmi Susanti ${ }^{2}$ \\ Universitas Pamulang, Banten \\ Email : dosen02059@unpam.ac.id
}

\begin{abstract}
ABSTRAK
Penelitian ini bertujuan menganalisis :1) Peran BIMBA-AIUEO Pamulang Permai dalam meningkatkan kemampuan membaca siswa 2) Standar Proses yang sudah dilakukan dalam meningkatkan kemempuan membaca siswa. Objek penelitian ini adalah BIMBA -AIUEO Pamulang Permai. Penelitian ini menggunakan combine metode dengan metode studi kasus. Hasil penelitian menunjukkan bahwa:1) Peran BIMBA-AIUEO Pamulang Permai dalam meningkatkan kemampuan membaca siswa cukup baik, sesuai dengan dasar hukum /PP tentang Manajemen pembelajaran UU No 20 tahun 2003, 2) Standar Proses yang dilakukan sudah baik penyusunan silabus dan RPP sesuai dengan kurikulum Pendidikan nasional. Pelaksanaan proses pembelajaran yaitumetode, media, sumber belajar yang berlangsung kooperatif, kreatip serta dialogis. Poin total IFAS EFAS BIMBA ialah 2,68 serta 2,5. Menunjukkan power BIMBA lebih kuat dari pada kelemahan dan teknik penerapan kelola internal pada tingkat sedang. Diagram SWOT BIMBA berada di Kuadaran 1.
\end{abstract}

Kata Kunci : Manajemen Pembelajaran, IFAS, EFAS

\begin{abstract}
The purpose of the research was to analyse : 1)The role of BIMBA-AIUEO Pamulang Permai in order to increase the student's reading skill 2) The standard process has been done in order to increase student's reading skill. The object of the research was BIMBA AIUEO Pamulang Permai. The research used the approach of qualitative analysis with study case method.The result of the research showed that : 1). The role of BIMBA -AIUEO Pamulang Permai in order to increase the student's reading skill was good enough, and was in accordance with the legal basis/ PP tentang Manajemen Pembelajaran UU No 20 tahun 2003. 2) The standard process has been done in order to increase student's reading skill was good, the syllabus composing and RPP were in accordance with the national education curriculum. The action of learning process was learning method, media, and source that went on cooperatively, creatively, and dialogicly. The value of IFAS and EFAS of BIMBA were 2,68 and 2,5. It showed that the strength was stronger than the weakness.Matriks SWOT BIMBA was in quadarnt 1.
\end{abstract}

Keywords : Learning Method, IFAS, EFAS

\section{PENDAHULUAN}

Pendidikan merupakan radas paling taktis, intiar permulaan guna memprogresif. potensi sumber dayamanusia, pendidikanlah yang paling kapabel merespon tantangan zaman [1]. Domain pendidikan meerupakan pemegang kendali paling jitu dalam pembangunan yang sedang berlanjut, diyakini cara yang tepat untuk memajukan kadar mutu manusia itu sendiri [2]. Kejayaan untuk pembangunan mutu setiap insan yang dipelihara dan diperuncing melalui varietas sekolah atau dengan kata lain pendidikan $[3,4]$. yang dilakukan dapat melalui lorong pendidikan yang resmi padanan maupun tidak.

Dilema pendidikan yang dihadapi Indonesia ialah daifnya taraf pendidikan pada setiap hierarki pendidikan. "Permasalahann krusial bangsa saat ini tahun 2012 PISA 
(Programme for International Study Assessment) menempatkan Indonesia sebagai salah satu negara dengan peringkatt terendah dalampencapaian mutu pendidikan yang pemeringkatan tersebut dapat dilihat dari skor yang dicapai pelajar usia 15 tahun dalam kemapuan mebaca, matematiika, sains (UNESCO 2012) menyajikan laporan Indonesia menduduki tingkat ke-64 dari 120 "(UNDP) 2011 "menyajikan laporan "Indeks Pembangunan Manusia" , "Indonesia ditingkat 108 pada 2010 dan memburuk pada tahun 2012 berada ditingkat 124. Sebaliknya di tahun 2016 IPPI mengalami kegagalan dan berada ditingkat 133 dari 188. UNDP mengungkapkan peforma pelajarlndonesia dibawah rata rata dari negara di wilayah ASEAN.

Peneliti memberikan pembatasan hal dalam kajian ini yaitu Peranan Managemen dalam menaikan taraf kapabilitas membaca siswa studi pada "BIMBA-AIUEO Pamulang Permai" Seperti apa peran manajemen pembelajaran dalam menumbuhkan kemampuan membaca siswa, dan bagaimana Mengampukan mekanisme yang sudah dilakukan "BIMBA- AIUEO Pamulang Permai" dalam meningkatkan kapabilitas baca siswa.

\section{LANDASAN TEORI}

Konsep Manejemen Sumber Daya Manusia lalah rangkaian upaya penyesuaian diri dengan pengembangan yang tanpa batas. Sangat mendukung untuk menekan pemborosan, karena diterapkan sikap teliti serta sikap cermat, bekerja meraih sasaran bersama, maka diperlukan item-item proses yang memerhatikan pada kebijakan merencanakan, mengorganisasikan serta pengontrolan. Guna membantu memberi keseluruhan gambaran dari pengambilan akhir keputusan strategis $[5,6]$.

\section{Manejemen Pembelajaran}

Manajemen mencakup kegiatan untuk mencapai tujuan yang dilakukan oleh individu yang menyumbangkan upaya terbaiknya melalui tindakan-tindakan yang telah ditetapkan sebelumnya [7], mencakup pengetahuan tentang apa yang harus dilakukan [8], menetapkan cara yang harus dilakukan, mengukur efektivitas usaha-usaha yang dilakukan, menetapkan dan memelihara kondisi lingkungan yang dapat memberikan responsi ekonomis, psikologis, sosial, politis, dan sumbangan-sumbangan teknis, serta pengendaliannya.

\section{Kemampuan membaca}

Menurut Mulyasa bahwa "hasil belajar adalah prestasi yang dihadapi, dilaksanakan oleh peserta didik" [9]. Menurut Harianto bahwa "hasil belajar yaitu sebuah kegiatan belajar mengajar yang menghendaki terciptanya tujuan belajar mengajar, dimana hasil belajar peserta didik ditandai dengan standar nilai" [10]. Dapat disimpulkan hasil belajar adalah perolehan nilai siswa pada setiap mata pelajaran setelah menjalani proses belajar.

Dalam riset yang dilakukan oleh Winata \& Friantini dikemukakan, bahwa membaca adalah hal mendasar bagi setiap manusia [11]. Dikarenakan, kemampuan membacara adalah salah satu cara bagaimana manusia dapat menjalani hidup secara baik dan benar. Banyak hal yang berkaitan dengan bacaan, baik di dalam rumah maupaun di luar rumah. Hal serupa juga dikemukakan oleh Prafitriani, et al., mampu membaca berarti mampu bertindak, karena secara tidak sadar kemampuan ini akan merangsang otak bagaimana bersikap dana atau berperilaku [12]. Semakin baik kemampuan membaca seseorang maka kemampuan meresponsnya akan lebih baik. 


\section{METODOLOGI PENELITIAN}

Berikut ini dikemukakan beberapa rangkaian metode yang digunakan, guna memastikan penelitian dapat dilakukan dengan baik dan benar, di antaranya:

1. Tempat serta Waktu

Objek penelitian ini ialah "Bimbingan Belajar BIMBA-AIUEO Pamulang Permai" yang beralamatkan "Pamulang Permai I Blok C 44 no 1 Kecamatan "Pamulang Barat , Tangerang Selatan" dilaksanakan selama enam bulan

2. Metode Penelitian

Menggunakan combine metode. yang mana mendalami materi yang dihasilkan dengan mengeksplor langsung objek dan tentu dituangkan ke wujud deskripsi juga membahas persoalan yang tersedia, kemudian penyajian berbentuk pembahasan persoalan yang terjadi serta penyajian angka - angka.Ini memiliki strategi proses yang jelas.

3. Populasi sampel

Populasi di penelitian ini ialah seluruh orangtua siswa "BIMBA AIUEO Pamulang Permai Kota" TangerangSelatan berjumlah 50 orang

4. Teknik Penentuan Data

Sumber data yang diperlukan di penelitian ini : data sekunder serta data primer

5. Metode Analisis Data

Metode di penelitian ini ialah :

a. Validasi Konstruk

Dalam penelitian ini peneliti menggunakan dua teknik yaitu, "Triagulasi sumber " serta "Triagulasi metode". Yaitu proses mengecek ulang kebenaran suatu item, caranya membandingkan materi dari beberapa sumber disaat penelitan di waktu berbeda ". Adapun pada "Triangulangi sumber", materi dari beberapa sumber berbeda dilakukan perbandingan atas datanya ( Bahan di verifikasi ke bentuk kualitatif ). Selanjutnya pada " Metode triangulasi " dilakukan pengecekan kevalidan materi, dilakukan dengan cara perbandingan pola yang regular dengan perbedaan waktu.

b. Analisis SWOT

Ialah bentukan analisis situasi dengan mengidentifikasikan ragam factor secara berunut terhadap kekuatan-kekuatannya (Strengths), kelemahannya (Weaknesses) kesempatannya (Opportunities) ,berbagai ancaman (Threats) lingkungan sekitar guna merumusskan ketepatan taktik.

Setelah" validasikonstruk" selesai dilanjutkan dalam format "IFAS EFAS matrix". Dengan tujuan membuat pertimbangan Teknik yang tepat untuk diterapkan pada objek. Dengan mengutamakan keproduktifan serta ketepatan strattegi yang bernilai lebih taktis. Metode ini akan menghasilkan alternative rekomendasi. 


\section{Hasil Penelitian dan Pembahasan}

\section{Tabel 1. Penilaian bobot faktor strategis internal}

\begin{tabular}{|c|c|c|c|c|}
\hline \multicolumn{2}{|c|}{$\begin{array}{l}\text { No Faktor Strategi Internal } \\
\text { Strengt }\end{array}$} & \multicolumn{2}{|c|}{$\begin{array}{l}\text { Kualifikasi Jumlah } \\
\text { ABCDE F }\end{array}$} & Bobol \\
\hline 1 & Guru berpengalaman & 11221 & 7 & 0.08 \\
\hline 2 & Lembaga unggullan & $3 \quad 3332$ & 14 & 0.08 \\
\hline 3 & Kuriculum sesuai Diknas & $32 \quad 232$ & 12 & 0.12 \\
\hline 4 & S D M berpengalaman & 32233 & 13 & 0.08 \\
\hline 5 & Pasilitas lengkap & 22232 & 11 & 0.06 \\
\hline 6 & $\begin{array}{l}\text { Prosessistem balajar } \\
\text { "EducationMovie" terkait attitude dan } \\
\text { pengetahuanumum }\end{array}$ & 23321 & 11 & 0.12 \\
\hline \multicolumn{2}{|c|}{ Total } & & 68 & 0,54 \\
\hline & KELEMAHAN & \multicolumn{2}{|l|}{$A B C D$} & \\
\hline 1 & Kelas sempit & 121 & 4 & 0.14 \\
\hline 2 & Parkiran kurang lapang & 213 & 6 & 0.16 \\
\hline 3 & Keheningan tidak menyongkong & 121 & 4 & 0.08 \\
\hline \multirow[t]{2}{*}{4} & Guru jumlah minimum & 332 & 8 & 0.08 \\
\hline & & & 22 & 0,46 \\
\hline \multicolumn{2}{|c|}{ Tota } & & & 1,0 \\
\hline
\end{tabular}

Sumber: Data penelitian, 2019

Tabel 2. Penilaian bobot faktor strategis eksternal

\begin{tabular}{|c|c|c|c|c|c|c|}
\hline \multirow[t]{2}{*}{ No } & \multirow{2}{*}{$\begin{array}{l}\text { Penilaian bobot faktor strategis eksternal } \\
\text { PELUANG }\end{array}$} & \multicolumn{3}{|c|}{ Kualifikasi } & \multirow[t]{2}{*}{ Jumlah } & \multirow[t]{2}{*}{ Bobot } \\
\hline & & A & $\mathrm{B}$ & $\mathrm{C}$ & & \\
\hline 1 & Kesempatan kerjasama dengan badanpsikologi & & 2 & 1 & 3 & 0.14 \\
\hline 2 & Kesempatan menjadi badan percontohan & 2 & & 1 & 3 & 0.18 \\
\hline 3 & Kesempatan menjadi PAUD mengglobal & 2 & 2 & & 4 & 0.16 \\
\hline \multicolumn{2}{|c|}{ Total } & & & & 10 & 0,48 \\
\hline No & ANCAMAN & A & B & C & Jumlah & Bobot \\
\hline 1 & Anak usia dini di sekitar jumlahnya berkurang & & 2 & 1 & 3 & 0.12 \\
\hline 2 & Kwantitas PAUD berlevel diatasnya & 2 & & 1 & 3 & 0.22 \\
\hline 3 & $\begin{array}{l}\text { Beberapan rencana yang ditiru } \\
\text { lembagabimbingan } \\
\text { belajar lain }\end{array}$ & 2 & 2 & & 4 & 0.18 \\
\hline JUM & ILAH TOTAL & & & & 10 & 1.00 \\
\hline
\end{tabular}

Sumber: Data penelitian, 2019 
Tabel 3. Matrik IFAS

\begin{tabular}{llccc}
\hline \multicolumn{1}{c}{ Faktor } & Integrity & Rating & Score \\
\hline & IFAS STRENGTH & & & \\
1 & Guru Berpengalaman & 0,08 & 4 & 0,32 \\
2 & Lembaga Unggulan & 0,08 & 3 & 0,24 \\
3 & Kurikulum Sesuia DIKNAS & 0,12 & 4 & 0,48 \\
4 & SDM Berkompeten & 0,08 & 3 & 0,24 \\
5 & Pasilitas Lengkap & 0,06 & 2 & 0,12 \\
6 & Proses Komposisi Belajar & 0,12 & 3 & 0,36 \\
& & $\mathbf{0 , 5 4}$ & & $\mathbf{1 , 7 6}$ \\
& & & & \\
1 & Kelas Sempit & 0,14 & 1 & 0,14 \\
2 & Parkir & 0,16 & 1 & 0,16 \\
3 & Keheningan & 0,08 & 2 & 0,16 \\
4 & Guru Minimum & 0,08 & 2 & 0,16 \\
& & $\mathbf{0 , 4 6}$ & & $\mathbf{0 , 9 2}$ \\
\hline
\end{tabular}

Sumber: Data penelitian, 2019

Ket : "Integrity" atau "Bobot" yaitu sejauh mana elemen mempunyai andil penting bagi Lembaga.

"Rating" yaitu kondisi nyata

"Score" yaitu "bobot" dikalikan dengan "rating"

Luaran pada table matrik EFAS merumuskan :

Keseluruhan dari poin IFAS memberikan petunjuk akan keadaan internal pada elemen kekuatan yaitu 1,76 dan keadaan internal pada elemen kelemahan 0,92. Ini mendefinisikan power BIMBA lebih besar dibandingkan kelemahan yang dimiliki BIMBA. Poin akhir keseluruhan IFAS 2,68 bermakna penerapan terhadap pengelolaan internal BIMBA berada di tingkat sedang.

\section{Tabel 4. Matrik EFAS}

\begin{tabular}{llll}
\hline \multicolumn{4}{c}{ Integrity Rating Score } \\
\hline EFAS Opportunity & & & \\
Kesempatan kerjasama dengan badan psikologi & 0,14 & 3 & 0,42 \\
Kesempatan menjad bahan percontohan & 0,18 & 3 & 0,54 \\
Kesempatan menjadi PAUD mengglobal & 0,16 & 3 & 0,48 \\
& 0,48 & & 1,44 \\
EFAS Threats & 0,12 & 4 & 0,48 \\
Anak usia dini disekitar berkurang & 0,22 & 1 & 0,22 \\
Kuantitas PAUD belevel di atasnya & 0,18 & 2 & 0,36 \\
Beberapa rencana ditiru Lembaga bimbimngan \\
belajar lain & 0,52 & & 1,06 \\
\hline Total & 1,0 & & 2,5 \\
\hline
\end{tabular}

Sumber: Data penelitian, 2019

Keluaran dari poin EFAS memberikan petunjuk akan situasi eksternal pada elemen risiko bisa dilihat pada luaran poin EFAS elemen peluang/prospek 1,44 serta 
situasi eksternal elemen ancaman 1,06. Poin ahir keseluruhan EFAS 2,5 ini bermakna : BIMBA punya risiko lebih kecil dibanding prospek yang ada.

Poin "bobot" 0,18 pada badan percontohan (poin tertinggi pada kesempatan) maknanya elemen ini menjadi prospek tertinggi bagi BIMBA untuk berkembang. Poin 0,16 pada kesempatan PAUD menggobal dan 0,14 pada kerjasama maknanya elemen ini menjadi prospek sedang bagi Lembaga BIMBA. Poin 0,22 pada jumlah PAUD (poin tertinggi pada risiko/ancaman) maknanya jumlah PAUD lain menjadi risiko terbesar pada bimba. Poin 0,18 dan 0,12 pada peniruan rencana belajar serta usia dini berkurang maknanya ini menjadi risiko sedang untuk BIMBA.

Skema ini memberi keterangan bagaimana kita merekognisi prospek serta risiko.

Penyusunan table EFAS berpijak pada kegiatan yang kita dapatkan dari pemantauan. serta pengukuran zona eksternal yang berguna untuk mendapat big picture situasi yang ada dan yang akan dihadapi. Dengan keterlibatan elemen eksternal ini kita bisa mengkaji lebih lanjut dampak atau impaknya, bila memberi impak yang baik maka dimaknai sebagai prospek, dan dimaknai risiko jikalu impak tidak baik.

Setelah kita tahu power organisasi, langkah selanjutnya yaitu melihat posisi sekarang dengan menyusun diagram seperti berikut ini, selanjutnya kita bisa membidik eksekusi yang harus dilakukan.

Tabel 5. Matrik Internal Eksternal (IE)

\begin{tabular}{|c|c|c|c|c|}
\hline & \multicolumn{2}{|r|}{ Positiip } & \multicolumn{2}{|r|}{ Negatip } \\
\hline & \multicolumn{2}{|r|}{ STRENGTH } & \multicolumn{2}{|r|}{ Weaknesses } \\
\hline & 1 & Guru berpengalaman & 1 & Kelas sempit \\
\hline & 2 & Lembaga unggullan & 2 & Parkiran kurang lapang \\
\hline & 3 & Kuriculum sesuai Diknas & 3 & $\begin{array}{l}\text { Keheningan tidak } \\
\text { menyongkong }\end{array}$ \\
\hline \multirow{5}{*}{ Internal } & 4 & SDM berkopeten & 4 & Guru jumlahnya minim \\
\hline & 5 & Fasiliitas lengkap & & \\
\hline & 6 & $\begin{array}{l}\text { "Education Movie" terpaut } \\
\text { juga attitude pengetahuan } \\
\text { umum }\end{array}$ & & \\
\hline & & Peluang & & Ancaman \\
\hline & 1 & $\begin{array}{l}\text { Kesempatan bekejasama } \\
\text { dengan badan psikologi }\end{array}$ & 1 & $\begin{array}{l}\text { Anak usia dini di } \\
\text { sekitar jumlahnya semakin } \\
\text { mengurang }\end{array}$ \\
\hline \multirow[t]{2}{*}{ Eksternal/luar } & 2 & $\begin{array}{l}\text { Kesempatan jadi } \\
\text { percontohan }\end{array}$ & 2 & $\begin{array}{l}\text { Kwantitas PAUD berlevel di } \\
\text { atasnya. }\end{array}$ \\
\hline & 3 & $\begin{array}{l}\text { Kesempatan jadi PAUD } \\
\text { mengglobal }\end{array}$ & 3 & $\begin{array}{l}\text { Beberapa rencana yang ditiru } \\
\text { oleh lembaga bimbingan } \\
\text { belajar lain }\end{array}$ \\
\hline
\end{tabular}

Sumber: Data penelitian, 2019

Penerapan akan "Skenario Strategi " berpedoman matrik SWOT, ditentukanlah skenario pengelolaan BIMBA :

1. "Strengh-Opportunity" / SO, yaitu memanfaatkan prospek dengan menggunakan power tinggi yang dimiliki, tindakannya :

a. publisitas BIMBA dilakukan beruntun dengan cara offline ataupun daring 
b. Meakukan bimbingan aset melalui media social atau dengan memanfaatkan "word of mouth " yaitu dengan menonjolkan keunggulan pasar ini di bandingkan dengan pasar lain, misal dalam hal harga dan lainnya.

c. Melajukan produk berkelas sebanding.

d. silabus berjalan sinkron dengan DIKNAS

SO dipilih jika kita memiliki power tinggi serta punya prospekyang bagus

2. "Weaknesses-Opportunity" / WO, ini dipilih jika kita tidak punya power sebaik kompetitor ,kelemahan kita banyak tapi prospeknya besar, jadi kita meminimalisasikan kekurangan dengan memanfaatkan prospek/peluang., WO dimaknai dengan sebutan teknik peningkatan modal. WO pada BIMBA :

a. Membangun potensi pegawai selama training

b. Memperluas cadangan pengajar untuk tenaga pengganti.

3. "Strength-Threats" / ST, ini dipilih jikalau risiko kita besar tapi power kita lebih unggul maka gunakan power untuk menghadapai risiko, sebutan lain "ST" ialah teknik peningkatan media serta infrastuktur. ST pada BIMBA :

a. Perbaikan fisik substansi

b. Membangun produk berkelas

c. Senantiasa mengoperasikan hal baru secara teratur seraya membentengi unggulnya produk

Poin Output IFAS EFAS menerangkan posisi BIMBA punya power tinggi 1,76 serta Risiko/ancaman tinggi 2,5. Jadi Teknik yang dipakai ST dimana menggunakan power untuk menghadapi risiko

4. "Weaknesses-Threats" / WT, ini dipilih jika posisi kita buruk sekali banyak kelemahan sserta risiko, segera mengimprove diri supaya lebih baik, harus pandai pandai menghindari risiko. Sebutan lainnya ialah teknik menguatkan kolaborasi. "WT" pada BIMBA :

a. Teratur mengadakan penilaian berkenaan produk

b. Menyediakan pengajar terbaik.

c. Mengajar training hingga punya teknik mengajar unggulan.

Ketika meghadapi lawan yang kuat tetapi prospek tipis atau tidak bisa meghadapinya langsung bisa diselsaikan dengan memakai cara - cara cerdik.

Karena tidak semua risiko harus dihadapi, ada trik lainnya tentu saja kalau kita tahu didepan ada risiko dan kita lemah maka cara terbaik ialah menghindarinya.

Matriks SWOT merumuskan teknik dan memutuskan batas batas dalam membuat sebuah produk : produk harus mencerminkan "STP", citra label apa yang akan ditanamkan pada pelanggan baik soal price ataupun edaran iklan.

Dalam membidik target dan penentuan price harus ditafsirkan level yang akan dituju, harus ada penggolongan potensial pelanggan kalangan menengah, atas ataukah bawah. Berpijak pada income, minat serta kultur. Kategori menengah yaitu bisa menggunakan Rp 40.000/ hari tanpa merasa berat. Inilah yang bisa ditelaah saat memetakan pelanggan. 


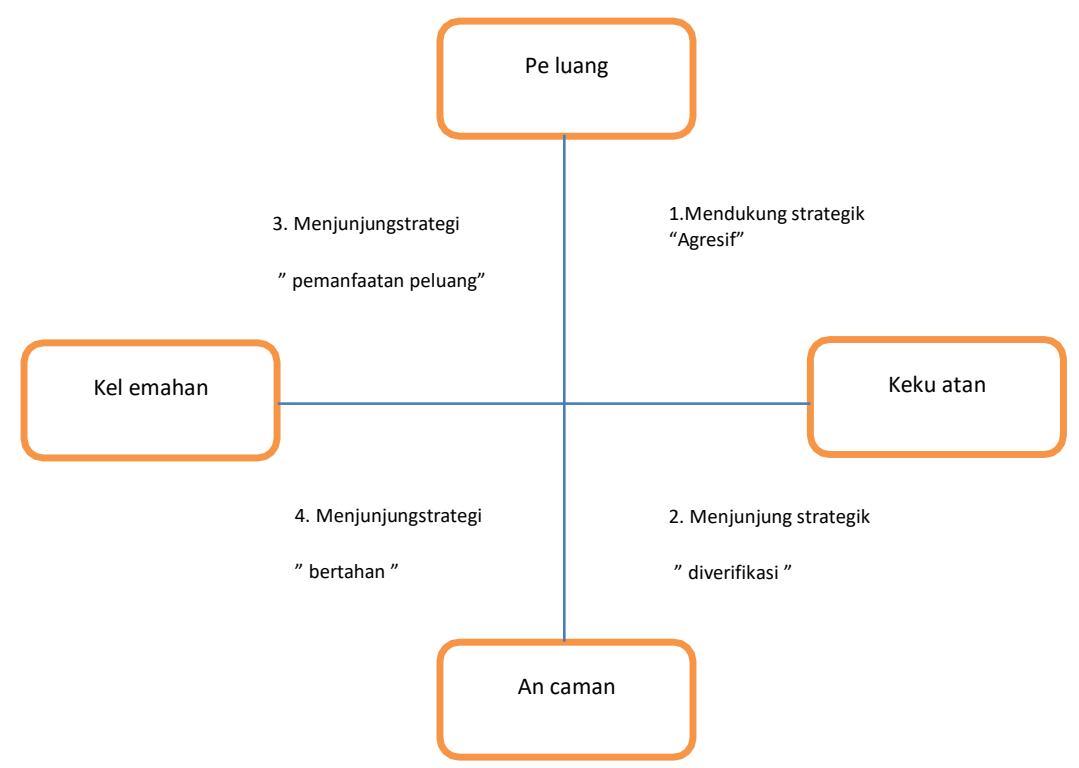

\section{Penjelasan}

\section{Gambar 1. Diagram SWOT}

1. KUADRAN I : terbilang cukup menguntungkan bagi Lembaga dimana punya kawasan penting, banyak kesempatan yang bisa difaedahkan dengan menyokong rencana penggunaan prospek .

2. KUADRAN II : walau banyak mengalami risiko namun Lembaga memiliki kekuatan dari sisi dalam dan siasat yang bisa dipertahankan

3. KUADRAN III : Lembaga berpeluangbesar punyai efek risiko

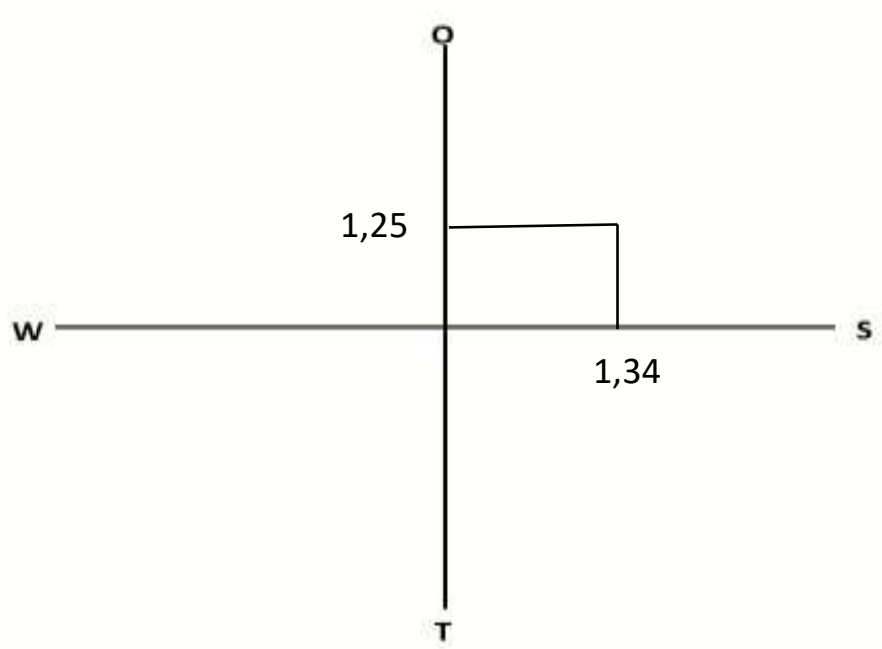

Gambar 1. Diagram SWOT 


$$
\begin{aligned}
& X=\frac{S+W}{2} \\
& X=\frac{1,76+0,92}{2} \\
& X=1,34
\end{aligned}
$$

$$
\begin{aligned}
& Y=\frac{O+T}{2} \\
& Y=\frac{1,44+1,06}{2} \\
& Y=1,25
\end{aligned}
$$

Bersumber hasil penghitungan maka BIMBA berada di kuadran I dengan koordinat $X=1,34$ dan koordinat $Y=1,25$

"KUADRAN I" : ini merupakan situasi yang sangat menguntungkan Lembaga BIMBA. Ini bermakna memiliki poin besar pada prospek dan power. Teknik yang seharusnya diimplementasikan dalam situasi ini ialah dukungan progres lembaga yang agresif.

\section{KESIMPULAN DAN SARAN}

Peranan manajemenpembelajaran sangatlahbesar, terbukti dengan banyaknya kemajuan dallam terampilnya membaca siswa, kemajuan kepribadian siswa yang positip terpaut dorongan serta antusiasme. Penerapan pembellajaran berjalan koperatif dan produktif. Standar proses yangdilakukan "BIMBA AIUEO Pamulang" telah dilangsungkan tertib, pengerjaan programstudi, RRP samadengan "kurikulum Pendidikan Nasional." Pendayagunaan saranaserta prosedur maksimum. Poin ahir keseluruhan IFAS EFAS BIMBA ialah 2,68 serta 2,5 menunjukkan power BIMBA lebih kuat daripada kelemahan dan teknikpenerapan kelola internal pada tingkat sedang. Diagram SWOT BIMBA berada di kuadran I Teknik yang diterapkan yaitu mensuport keagresifan pertumbuhan lembaga.

\section{DAFTAR PUSTAKA}

[1] Harras, H., Sugiarti, E., \& Wahyudi, W. (2020). KAJIAN MANAJEMEN SUMBER DAYA MANUSIA UNTUK MAHASISWA.

[2] Arifa, F. N., \& Prayitno, U. S. (2019). Peningkatan Kualitas Pendidikan: Program Pendidikan Profesi Guru Prajabatan dalam Pemenuhan Kebutuhan Guru Profesional di Indonesia. Jurnal Aspirasi, 10(1), 1-17.

[3] Mahmudah, A., \& Pustikaningsih, A. (2019). PENGEMBANGAN MEDIA PEMBELAJARAN INTERAKTIF BERBASIS LECTORA INSPIRE PADA MATERI JURNAL PENYESUAIAN UNTUK SISWA KELAS $X$ AKUNTANSI DAN KEUANGAN LEMBAGA SMK NEGERI 1 TEMPEL TAHUN AJARAN 2018/2019. Jurnal Pendidikan Akuntansi Indonesia, 17(1), 97-111.

[4] Wahyudi, W. (2018). THE INFLUENCE OF EMOTIONAL INTELLIGENCE, COMPETENCE AND WORK ENVIRONMENT ON TEACHER PERFORMANCE OF SMP KEMALA BHAYANGKARI JAKARTA. SCIENTIFIC JOURNAL OF 
REFLECTION : Economic, Accounting, Management and Business, 1(2), 211 220

[5] Salamah, U. (2019). Peningkatan Kualitas Pendidikan Melalui Kualifikasi dan Kompetensi Akademik. Journal EVALUASI, 3(1), 61-73.

[6] Anggranei, F. N. . (2020). REALITAS KOMPETENSI GURU PASCA SERTIFIKASI. SCIENTIFIC JOURNAL OF REFLECTION : Economic, Accounting, Management and Business, 3(4), 331-340

[7] Syamsuar, S., \& Reflianto, R. (2019). Pendidikan dan tantangan pembelajaran berbasis teknologi informasi di era revolusi industri 4.0. E-Tech: Jurnal IImiah Teknologi Pendidikan, 6(2).

[8] Walid, A., Sajidan, S., Ramli, M., \& Kusumah, R. G. T. (2019). Construction of the assessment concept to measure students' high order thinking skills. Journal for the Education of Gifted Young Scientists, 7(2), 237-251.

[9] Syah, D. N., Amin, A., \& Gumay, O. P. U. (2019). Hubungan Motivasi Belajar terhadap Prestasi Belajar IPA Terpadu. SPEJ (Science and Physic Education Journal), 2(2), 66-71.

[10] Palittin, I. D., Wolo, W., \& Purwanty, R. (2019). Hubungan motivasi belajar dengan hasil belajar siswa. Magistra: Jurnal Keguruan dan IImu Pendidikan, 6(2), 101-109.

[11] Winata, R., \& Friantini, R. N. (2019). Pengaruh motivasi belajar terhadap prestasi belajar matematika siswa kelas VIII SMP negeri 1 Kuala Behe. Jurnal Math Educator Nusantara: Wahana Publikasi Karya Tulis IImiah Di Bidang Pendidikan Matematika, 5(01), 43-50.

[12] Prafitriani, S., Umanailo, M. C. B., Indrayani, N., Lisaholit, S., \& Chamidah, D. (2019). pengaruh kecerdasan emosional terhadap hasil belajar matematika siswa kelas VII SMP Negeri 9 Buru. JISPO: Jurnal IImu Sosial dan IImu Politik, 9(2), 567-580. 